\title{
Improvement of Methodological Approaches to Determining Directions of Ensuring Financial Security of Insurance Companies of Ukraine
}

\author{
OLEG A. DIEGTIAR ${ }^{1}$, OLENA A. LUTSENKO ${ }^{2}$, LIUDMYLA A. POLYVANA ${ }^{3}$, \\ TETIANA A. PUSHKAR ${ }^{4}$, HANNA A. ZHOVTYAK ${ }^{5}$ \\ ${ }^{1}$ Department of Management and Administration, O.M. BEKETOV NATIONAL UNIVERSITY OF URBAN \\ ECONOMY IN KHARKIV, UKRAINE. E-mail: o.diegtiar6537@tanu.pro \\ 2,3 Department of Accounting and Audit, KHARKIV PETRO VASYLENKO NATIONAL TECHNICAL UNIVERSITY OF \\ AGRICULTURE, UKRAINE \\ 4,5 Department of Economy, O.M. BEKETOV NATIONAL UNIVERSITY OF URBAN ECONOMY IN KHARKIV, \\ UKRAINE
}

\begin{abstract}
Financial security of the insurance market significantly affects the financial, economic and social stability of society and should be included in the range of problems that are directly related to the issues of financial security of Ukraine. The main purpose of the article is to set out and solve the problem of improving methodological approaches to determining the directions of ensuring the financial security of insurance companies in Ukraine. The main functional tasks of financial security of insurance companies are identified. It has been proved that financial security is a component of economic security and a refined definition of this category has been provided. Destabilizing factors of influence on financial security of insurance companies have been identified and analyzed. A methodological approach to managing the financial security of an insurance company has been developed. A complex of proposals for the development of the insurance services market has been formed as a basis for strengthening the financial security of insurance companies. It was concluded that the insurance sector of Ukraine can actively develop provided that there is a clear theoretical and methodological justification of the toolbox, the implementation of a methodological approach to managing the financial security of the insurance company, taking into account all the problems and proposals for its continuous improvement and development in the changing conditions of the present.
\end{abstract}

Keywords: destabilizing factors, economic security, management, insurance market.

JEL Classification: G22, G28, F52. 


\section{Introduction}

The current state of development of the financial and economic sector of Ukraine is characterized by the urgent need to ensure the financial security of economic entities at the proper level in the conditions. Also, transformational processes in recent times in Ukraine are often accompanied by constant economic risks and threats, both internal and external, which are associated with the issue of resource support for the economic development of enterprises and companies. Therefore, the financial security of the insurance market significantly affects the financial, economic, and social stability of society and should be included in the range of problems that are directly related to the issues of financial security of Ukraine. The importance of the problem of determining the directions of ensuring the financial security of the insurance market is due to the influence of some factors, namely:

1. the financial crisis;

2. the geopolitical situation;

3. the inconsistency of the activities of international organizations;

4. inflationary processes.

All these factors contribute to the unpredictability of the processes taking place in its components at all stages of the work of insurance companies in the market. The above situation indicates that the further effective development of insurance companies is associated with the introduction of a universal and effective methodological approach to ensuring financial security, which will include the identification of factors affecting the state of financial security as a hierarchical system, identify external and internal threats, the relationship of individual components of this complex internal structure and hierarchical composition of the structure (Derkach, 2012).

The purpose of the article is to improve methodological approaches to determining the directions of ensuring the financial security of insurance companies in Ukraine. To achieve the purpose, the following general and specific tasks are solved in the article:

1. to identify the main goal and functional objectives of the financial security of insurance companies as the baseline for the effectiveness of the implementation of the methodological approach;

2. to summarize approaches to the definition of the category "financial security" of insurance companies;

3. to identify destabilizing factors affecting the financial security of insurance companies;

4. to clarify the concept of "financial security" of the insurance company in modern conditions of development;

5. to develop a methodological approach to managing the financial security of the insurance company;

6. to systematize problematic aspects of the insurance sector of Ukraine;

7. to form a complex of proposals for the development of the insurance services market as a basis for strengthening the financial security of insurance companies in the changing environment of Ukraine.

The main objective of the financial security of in surance companies has been found, namely, to guarantee the stable and most effective functioning of insurance companies at present and to form the foundations for increasing the development potential in the future. Based on the goal of financial security of insurance companies, the following functional objectives of financial security regarding insurance companies were defined: improving the efficiency of financial work, ensuring and maintaining the financial stability and independence of the enterprise, enhancing the formation of capital, optimizing its structure, increasing competitiveness in the insurance market, achieving high liquidity of current assets, supporting and increasing the level of business activity, 
protecting trade secrets and information. The concept of "financial security" of the insurance company has been found as a characteristic dynamic financial condition of the insurance company, which is characterized by the protection of its priority financial interests from identified challenges, threats, risks and dangers, the ability to ensure the implementation of its mission and operational and strategic financial tasks, as well as the continuous economic development and increase of available financial resources.

The problem of theoretical and methodological ensuring the financial security of enterprises and insurance companies was dealt with by many economists (Derkach, 2012; Gevorkyan et al., 2018; Lazareva, 2014; Berdar, 2011; Kuzmenko, 2018; Vasyltsiv et al., 2012; Nepomnyashchyy et al., 2020; Lelechenko et al, 2020; Bernardino et al., 2020) at different times. They have developed modern methods for assessing and analyzing financial security, but, despite their numerous studies, the determination of the directions for ensuring the financial security of insurance companies in the changing financial and economic conditions of Ukraine remains unresolved.

\section{The Definition of the Category "Financial Security" of Insurance Companies}

In the current context, insurance companies, under the influence of various environmental factors, often face many threats to the sustainable functioning of their financial system, which determines the need to improve methodological approaches to ensuring financial security. This will create a system of protection of economic interests and develop a complex of preventive management solutions that will ensure the competitiveness of the insurance company in the domestic and foreign markets.

Table 1 Functional objectives of financial security of insurance companies

\begin{tabular}{|l|l|l|}
\hline No. & \multicolumn{1}{|c|}{$\begin{array}{c}\text { Functional objectives of financial } \\
\text { security }\end{array}$} & $\begin{array}{c}\text { A general description of the objectives and result of } \\
\text { their achievement }\end{array}$ \\
\hline 1 & Improving financial performance & $\begin{array}{l}\text { The development and implementation of measures to } \\
\text { minimize or neutralize possible or existing threats to } \\
\text { financial security and protect the company's financial } \\
\text { interests }\end{array}$ \\
\hline 3 & $\begin{array}{l}\text { Ensuring and maintaining financial } \\
\text { sustainability and independence of the } \\
\text { enterprise }\end{array}$ & $\begin{array}{l}\text { The ability to control the state and movement of resources, } \\
\text { the ability to take advantage of competitive advantages; } \\
\text { providing safeguards for the effective operation and } \\
\text { deterrence of destabilizing factors }\end{array}$ \\
\hline 4 & $\begin{array}{l}\text { Increasing competitiveness in the insurance } \\
\text { market }\end{array}$ & $\begin{array}{l}\text { Increased financial independence and flexibility of capital } \\
\text { flows to prevent crises in the functioning and development } \\
\text { of a changing environment }\end{array}$ \\
\hline 5 & $\begin{array}{l}\text { Increase efficiency of a company's competitive advantage } \\
\text { utilization, preservation and/or expansion of the market } \\
\text { segment, the rational realization of identified reserves of } \\
\text { competitive potential in conditions of limited resources }\end{array}$ \\
\hline 7 & Achieving high liquidity of current assets & $\begin{array}{l}\text { Identification of needs for current assets required for the } \\
\text { continuity of insurance services, optimization of volume } \\
\text { and structure of current assets; providing current assets to } \\
\text { sources of finance; finding out the optimal relationship } \\
\text { between different sources of financing of current assets } \\
\text { and using low-cost ways to replenish current assets in the } \\
\text { course of the company's activities }\end{array}$ \\
\hline Support and increase business activity & $\begin{array}{l}\text { Development and adoption of effective management } \\
\text { decisions on the planning of the main indicators of the } \\
\text { company's activity, ensuring the specified rate of their } \\
\text { growth, showing activity to attract investment resources }\end{array}$ \\
\hline
\end{tabular}

Note that for most developed countries in Europe and the world, the insurance business is profitable both for insurers and gives protection and benefit to users of insurance services as well. The level of profitability and cost-effectiveness in this sector of services is significantly higher than the average in the economy. In these countries, $85-90 \%$ of objects are usually insured, while in 
Ukraine less than $10 \%$ of objects are insured, and in the market of life less than $1 \%$. It should also be emphasized that more than $50 \%$ of the volume of insurance premiums is income from endowment life insurance in the world practice.

To summarize the essence of the concept of "financial security," it is appropriate to determine the fundamental sources and approaches of economists who became the founders of this scientific direction and created a basis for its interpretation from multi-level positions with the definition of certain features and connections of each. The formation of a methodological basis founded on a certain definition will make it possible to justify the list and action of factors influencing and determining both the state of financial security itself and the management actions to form and preserve the financial system as a whole, as well as its components with corresponding characteristics (Lazareva, 2014).

The main goal of the financial security of the insurance company is to guarantee its stable and most effective functioning at present and to form the foundations for increasing the development potential in the future. In this context, the main functional tasks of financial security regarding insurance companies can be distinguished in Table 1. Based on the set goals and objectives (Table 1), approaches to the definition of the category "financial security" of insurance companies can be summarized in Figure 1.

The approaches to the definition of the financial security category of insurance companies resented in figure 1 are not separate from each other but should be considered as a system of definitions of this category. It should be noted that according to the first approach (Figure 1), financial security is a component of economic security, the most successful definition of which is the following: the ability of the insurance company to effectively develop and carry out financial and economic operations in a changing internal and external environment, that is, the state of protection of its important interests from the influence of destabilizing factors to ensure stability in the short and long term (Pilipenko, 2017). Therefore, it is appropriate to investigate varieties of destabilizing factors, provide a summary of their definition at the level of their impact on the insurance company in Figure 2.

Figure 1 Summary of approaches to the definition of the category "financial security" of insurance companies

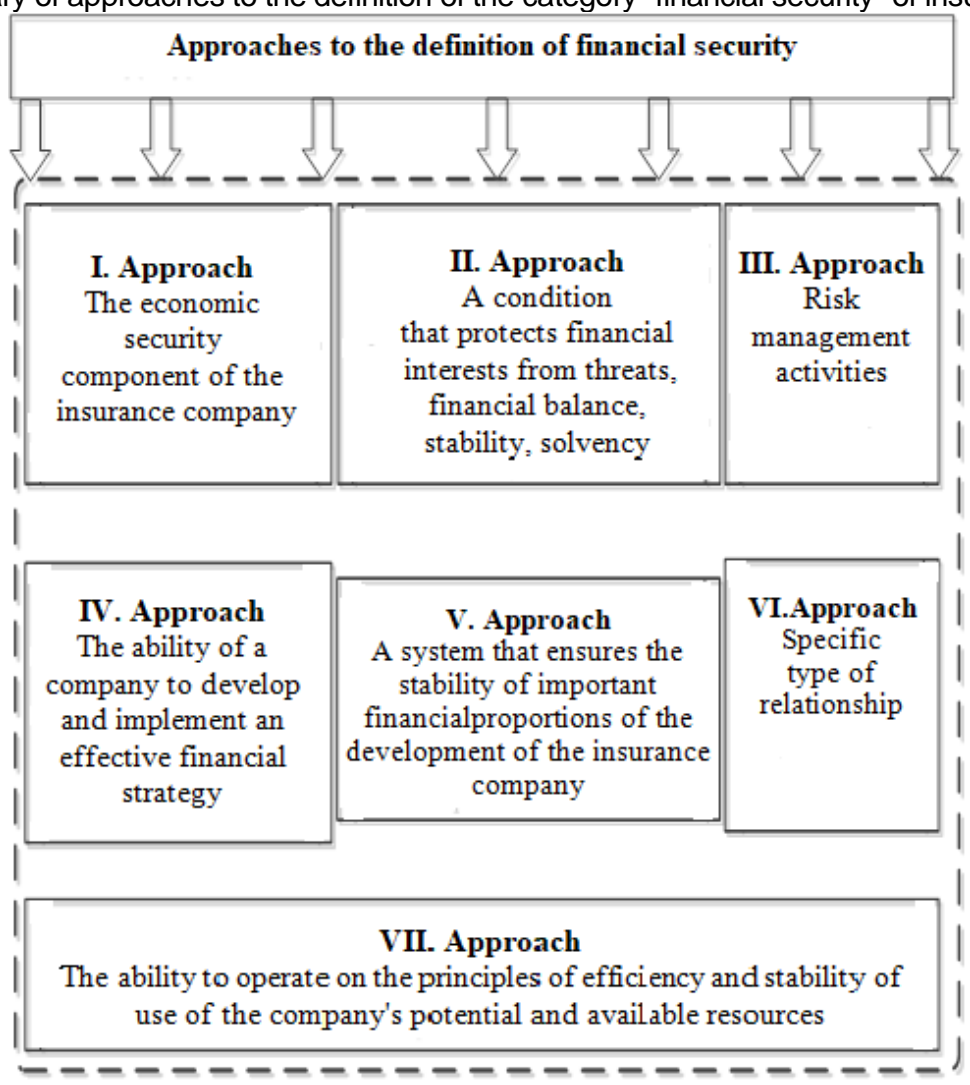

Source: Arefieva et al., 2014; Zhuravka et al., 2018. 
Figure 2 Destabilizing factors of influence on the financial security of insurance companies

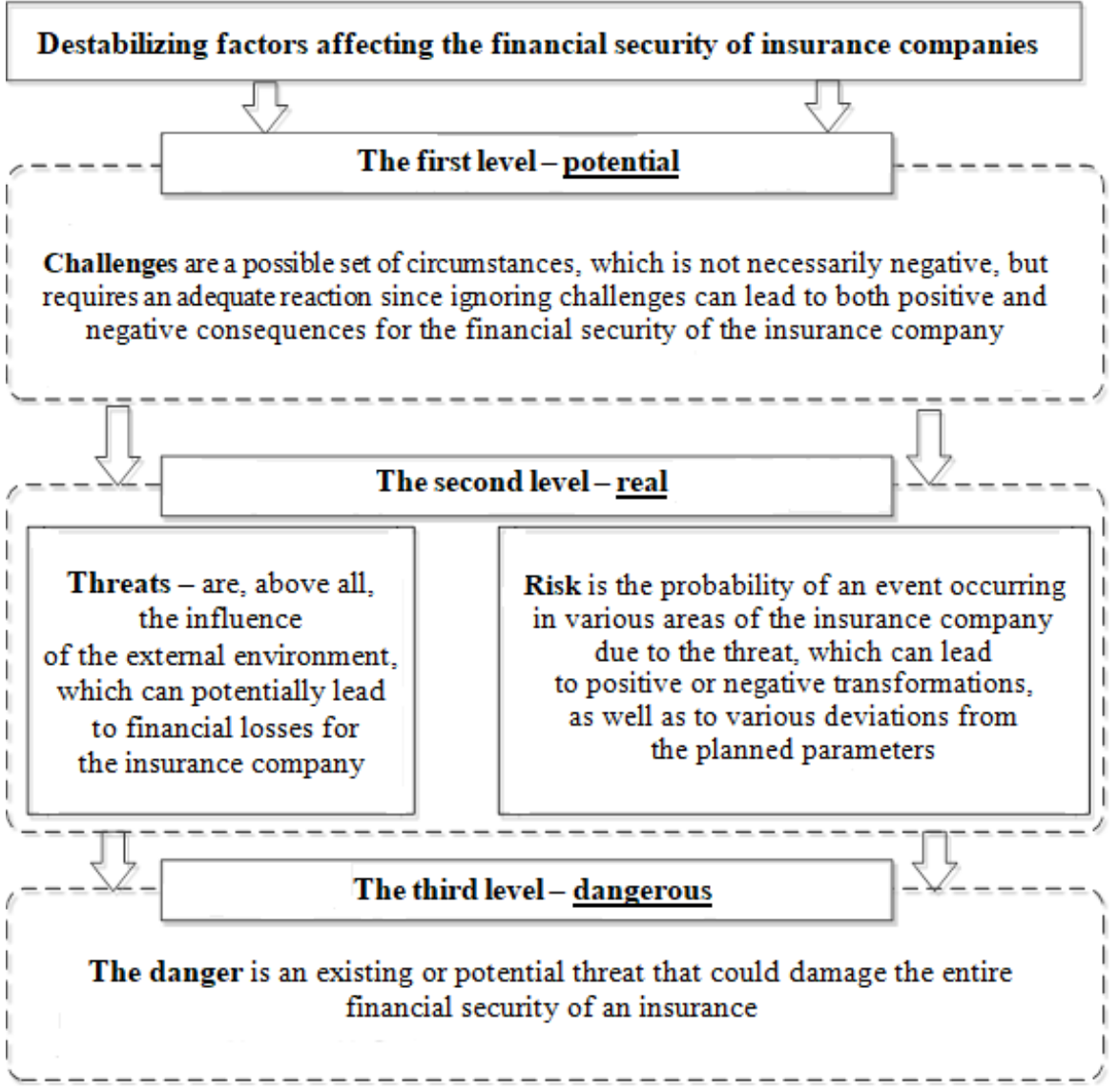

Source: Leashenko, 2015; Boiko, 2017; Rudnichenko, 2013.

As can be seen from the definition of "threats" (Figure 2), they are the main condition for negative consequences for the financial security system of insurance companies. In the course of the synthesis of literary sources (Romanenko, 2016; Diegtiar et al., 2019; Martins Carvalho, 2019) and own studies, the following types of relevant threats can be determined:

1. continuous changes in the legal framework;

2. worsening of the crime rate financial situation;

3. high inflation (inflation barriers to long-term insurance);

4. fraud of insurance market entities;

5. crises in international financial markets;

6. outflow of capital abroad;

7. an inadequate system of insurance intermediaries;

8. rapid development of globalization;

9. insignificant level of insurance coverage;

10.high proportion of reinsurance;

11.imbalance of the insurance portfolio;

12. inefficient placement of insurance reserves;

13.insufficient liquid assets;

14.corruption schemes;

15. disclosure of trade secrets and other confidential information;

16. low investment attractiveness of insurance companies in the investment market of Ukraine and the world; 


\section{7. low availability of credit resources;}

18. incompetence of the management of insurance companies, etc.

Thus, a comprehensive study of the system of interrelated effects of destabilizing factors on the financial security of insurance companies will contribute to their timely identification and effective response to them. It should also be noted that it is impossible to completely avoid destabilizing factors in the modern financial and economic environment of Ukraine.

\section{Methodical Approach to Financial Security Management of the Insurance Company}

Based on the above, it can be concluded that the term "financial security" of an insurance company can be understood as the characteristic dynamic financial condition of an insurance company, which is characterized by the protection of its priority financial interests from identified challenges, threats, risks and dangers, the ability to ensure the implementation of its mission and operational and strategic financial tasks, as well as the continuous economic development and increase of available financial resources. Thus, in a general sense, the financial security management system of an insurance company, in turn, can be understood as an ordered set of elements that are interconnected and form single functional integrity that is intended to establish and maintain an appropriate level of financial security. In Figure 3, an effective and universal methodological approach to managing the financial security of the insurance company was developed, taking into account the studies conducted in the article.

Table 2 System of problematic aspects of the insurance sector of Ukraine when developing a strategy for ensuring the financial security of an insurance company

\begin{tabular}{|c|c|c|}
\hline No. & Problematic aspect & Kinds of insurance market problems \\
\hline 1 & Organizational and legal & $\begin{array}{l}\text { - the lack of a coherent state insurance policy; } \\
\text { - regulatory framework that is not suitable for modern realities; } \\
\text { - insufficient government regulation and control of insurance companies } \\
\text { and the insurance market in general; } \\
\text { - the practical absence of the organization of state supervision of insurance } \\
\text { activities; } \\
\text { - lack of effective organization of interaction between the insurance and } \\
\text { banking sectors of the economy }\end{array}$ \\
\hline 2 & Financial and economic & $\begin{array}{l}\text { - low or no effectual demand of legal entities and individuals for insurance } \\
\text { services; } \\
\text { - high inflation and recession of the economy; } \\
\text { - necessity of reinsurance of the major risks with the help of foreign } \\
\text { insurance companies }\end{array}$ \\
\hline 3 & Functional & $\begin{array}{l}\text { - a small and specific range of insurance services; } \\
\text { - imbalance of insurance portfolios of insurance companies of Ukraine; } \\
\text { - low technological effectiveness of insurance operations; } \\
\text { - lack of application of the innovative component in the insurance business } \\
\text { of Ukraine }\end{array}$ \\
\hline 4 & $\begin{array}{l}\text { Management and human } \\
\text { resources }\end{array}$ & $\begin{array}{l}\text { - insufficient qualification and professional level of specialists, managers, } \\
\text { and other personnel; } \\
\text { - absence or insufficiency of qualification requirements for insurance } \\
\text { company personnel } \\
\text { - low level of education in insurance (for example, in } 072 \text { "Finance, } \\
\text { banking, and insurance" specialty applicants for higher education often } \\
\text { focus only on the financial and banking sector, and insurance is allocated } \\
\text { much less time and attention) }\end{array}$ \\
\hline
\end{tabular}

Source: Zhuravka et al., 2018.

When developing a strategy for ensuring the financial security of an insurance company, must be taken into account that despite some growth in the main indicators of the level of development of the insurance market, it still remains insignificant in terms of authorized and equity capital, assets and insurance reserves. Insurance companies cannot accumulate a significant amount of investment resources, and therefore have a significant impact on the processes of expanded reproduction, the growth of the Ukrainian economy, and the well-being of society. In the competition to attract financial resources, the insurance market of Ukraine has significantly lost to the banking system (Gevorkyan et 
al., 2018). This is primarily contributed to systemic problems in insurance services, which can be grouped in Table 2.

Figure 3 Methodical approach to financial security management of the insurance company

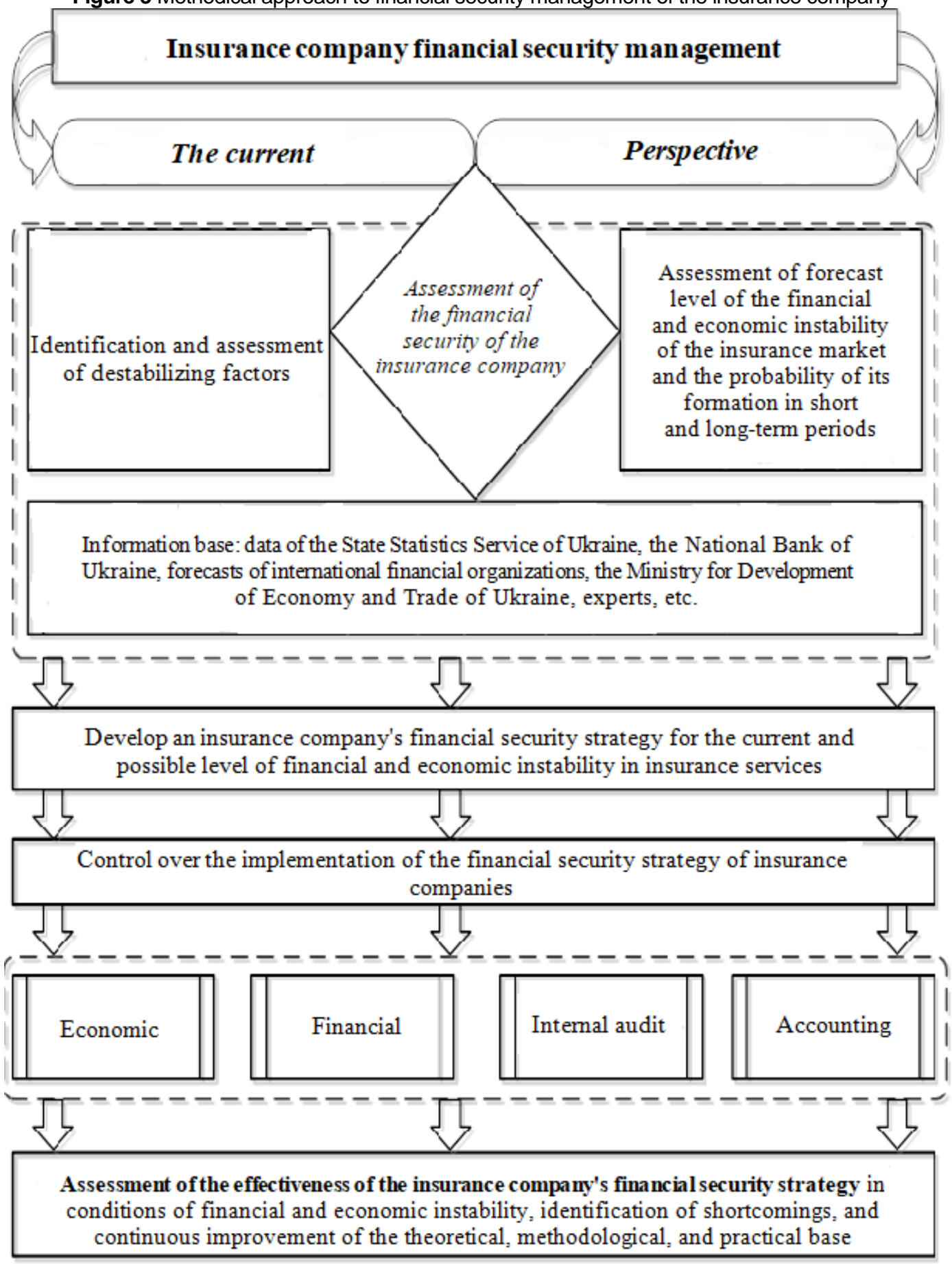

Source: Mordovtsev et al., 2020; Law of Ukraine “On Insurance”, 1996; Olinyk et al., 2014. 
Figure 4 Complex of proposals for the development of the insurance services market as a basis for strengthening the financial security of insurance companies

\section{Complex of proposals for the development of the insurance services market} as a basis for strengthening the financial security of insurance companies

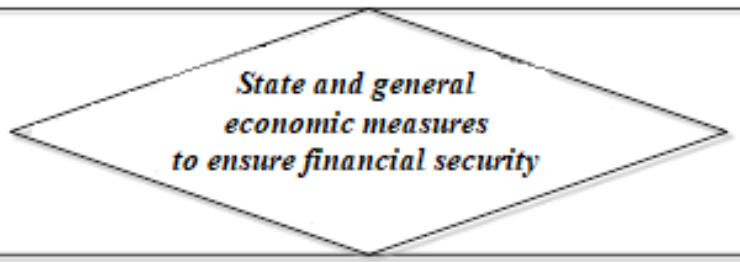

1. Improving the solvency of the population through the development of the

financial and economic sector

2. Improving the tax system of insurers

3. Availability of reliable and profitable instruments for investments of insurance companies

4. Decrease in inflation, stabilization of the national currency

5. Implementation of effective insurancepolicy at the state and municipal levels

6. Ensuring the effective development of the insurance market and creating conditions for the activities of insurance companies

7. Implementation of financial protection mechanism for insurance companies

8. Introduction of intemational corporate govemancerules for insurers

9. Improving the licensing of insurers

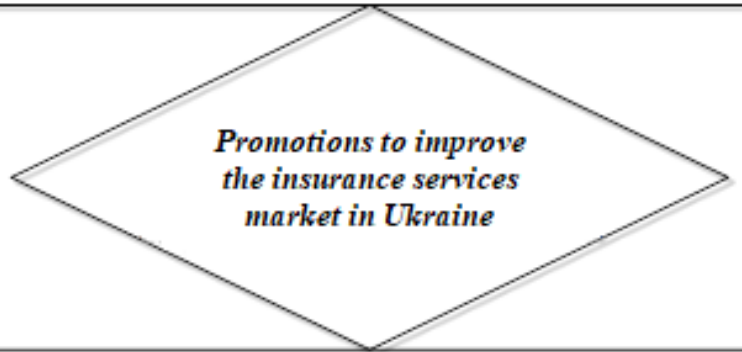

1. Restoration of confidence in insurance by individuals and legal entities

2. Development of measures to improve the insurance culture of the population of Ukraine

3. Provision of guarantees (funds) of full payments when concluding insurance contracts (especially life insurance)

4. Strengthening insurance supervision

5. Countering insurance fraud under insurance contracts by individuals and legal entities

6. Prevention of shadow money laundering through the insurance sector

Source: developed by the author on the basis of Law of Ukraine "On Insurance", 1996; Oliinyk et al., 2014.

Thus, the insurance sector of Ukraine can actively develop provided that there is a clear theoretical and methodological justification of the toolbox, the introduction of a methodological approach to managing the financial security of the insurance company, taking into account all the problems and proposals for its constant improvement and development in changing conditions of our time. Each proposal (Figure 4) should be fully investigated and put into practice. It is this development that will further increase the percentage of insurance services in the total percentage of the Ukrainian services market, which in turn will strengthen the financial security of insurance companies in the short and long term. 


\section{Conclusion}

Problem of improving methodological approaches to determining the directions of ensuring the financial security of insurance companies in Ukraine was set out and solved in the article. The following conclusions, observations and suggestions can be drawn from the studies undertaken.

Approaches to the definition of the category "financial security" of insurance companies were summarized and seven main approaches, which together most fully disclose this category for further research, were chosen. Destabilizing factors of influence on financial security of insurance companies are identified and it is proved that financial security is a component of economic security, which is defined as the ability of an insurance company to effectively develop and carry out financial and economic operations in a changing internal and external environment, that is, the state of protection of its important interests from the effects of destabilizing factors to ensure stability in the short and long term. The following destabilizing factors are identified, namely, challenges, threats, risks and dangers, their interrelationship is shown. A methodological approach to managing the financial security of an insurance company was developed, which includes both the current and the prospective level of assessment of the current state of financial security, and also determines the need to develop a strategy for ensuring financial stability and then monitor compliance. The problematic aspects of the insurance sector of Ukraine were systematized and their four main groups were rejected, namely: organizational-legal, financial-economic, functional, managerial and personnel. A complex of proposals for the development of the insurance services market has been formed as a basis for strengthening the financial security of insurance companies in the changing environment of Ukraine and a conclusion has been made, that insurance of Ukraine can be actively developed provided a clear theoretical and methodological justification of the toolbox, introducing a methodological approach to managing the financial security of the insurance company, taking into account all problems and proposals for its continuous improvement and development in the changing conditions of the present.

\section{References}

1. Arefieva, O.V., \& Kuzenko, O.L. (2014). Components of financial security by levels of subjects of financial relations. Scientific Bulletin of Kherson State University, 9(1), 184-7.

2. Berdar, M. (2011). Ensuring the financial security of business entities. Bulletin of Taras Shevchenko National University of Kyiv, 124/125, 73-6.

3. Bernardino, A.C., \& De Vidales Carrasco, I.M. (2020). The crisis and structural changes to the spanish banking sector: a comparison with other financing systems. Estudios De Economia Aplicada, 32(2), 535-566.

4. Boiko, I.V. (2017). Definitions of "risk", "threat", "danger" as objects of scientific research have been investigated in the fields of economic safety of enterprises. Priazovsky Economic Bulletin, 5, 94-8.

5. Derkach, O.M. (2012). Factors influencing the state of financial security of the insurance market. BiznesInform, 6, 187-90.

6. Diegtiar, O.A., Orlova, N.S., Kozureva, O.V., Shapovalova, A.M., \& Prykazka, S.I. (2019). Financial capacity of territorial communities: European experience and Ukrainian case. Collection of Scientific Works "Financial and credit activity: problems of theory and practice", 4(31), 516-26.

7. Gevorkyan, A.Yu., Druhova, O.S., \& Klepikova, S.V. (2018). Factors that influence the determination of investment attractiveness and business value. Bulletin of the National Technical University "Kharkiv Polytechnic Institute". Economic Sciences, 19, 131-4.

8. Kuzmenko, O.H. (2018). Financial security of the insurance market of Ukraine. Economics, Management, Finance: Theory and Practice. http://molodyvcheny.in.ua/files/conf/eko/06okt2014/31.pdf [Accessed Dec 4, 2020].

9. Law of Ukraine "On Insurance" dated March 7, 1996, No. 18. (1996). https://zakon.rada.gov.ua/laws/show/85/96-вp\#Text [Accessed Dec 3, 2020]. 
10. Lazareva, A.P. (2014). Financial security of the country: measures and main directions of strengthening. Bulletin of Priazovsky State Technical University, 27, 88-94.

11.Lelechenko, A.P., Diegtiar, O.A., Lebedinska, O.Y., Derun, T.M., \& Berdanova, O.V. (2020). Mechanisms of inter-state communications for solving sustainable development problems. Asia Life Sciences, 29(2), 1-9.

12. Liashenko, O.M. (2015). Conceptualization of economic security management of the enterprise. Kyiv: NISD.

13. Martins Carvalho, M.J.H. (2019). La teoría de la banca y la falacia de la innovación disruptiva en los servicios financieros. Estudios De Economia Aplicada, 37(3), 201-213.

14.Mordovtsev, O.S., \& Khrebtov, M.I. (2020). Methodical approach to cash flow management of an industrial enterprise. Bulletin of the National Technical University "Kharkiv Polytechnic Institute". Economic Sciences, 2, 3-8.

15.Nepomnyashchyy, O., Burmaka, T., Orlova, N., Nepomnyashchyy, O., Melnykovych, O., Medvedchuk, O, \& Lahunova. I. (2020). Social investment as a tool of corporate social responsibility realization in Europe. In: Education excellence and innovation management: a 2025 vision to sustain economic development during global challenges. The 35th IBIMA conference will be held in Seville, 1-2 April, 2020 (pp. 10151-62). Spain, Seville: IBIMA.

16.Oliinyk, V.M., \& Bondarenko, Ye.K. (2014). The concept of financial stability of the insurance company and the elements of influence on it. Problems and Prospects of Development of the Banking System of Ukraine, 39, 149-57.

17. Oliynyk, V.M. (2015). Profit modeling of insurance companies on the basis of network planning. Problems and Prospects of Development of the Banking System of Ukraine, 39, 149-57.

18. Pilipenko, N. (2017). Economic security as a dynamic characteristic of an enterprise. Economy and Society, 10, 338-42.

19. Romanenko, Y. (2016). Place and role of communication in public policy. Actual Problems of Economics, 176(2), 25-31.

20.Rudnichenko, Ye.M. (2013). Threat, risk, danger: the essence and relationship with the system of economic security of enterprises. Economy. Management. Enterprise, 25(1), 188-95.

21. Vasyltsiv, T.H., Boikevych, \& O.R., Karkavchuk, V.V. (2012). Financial and economic security of Ukrainian enterprises: strategy and support mechanisms. Lviv: Liha-Pres.

22.Zhuravka, O.S., Didenko, I.V., \& Kolesnyk, A.I. (2018). Factors influencing the financial security of insurance companies. Economics. Finance. Right, 5(5), 15-20. 